\title{
An Introduction to Josephine Herbst, Novelist
}

\author{
WINIFRED FARRANT BEVILACQUA
}

When a writer's work constitutes a thoughtful statement about life, when it projects a coherent vision of man in his private and social relationships, when it confronts contemporary problems with mature and unflinching objectivity, that writer deserves serious critical attention. Unfortunately, some authentic writers, especially those whose production is of uneven quality, remain only partially discovered while active, and almost entirely forgotten afterwards. Such is the case of Josephine Herbst. She made her debut in the 1920s, with stories and novels which earned her a reputation as a promising young talent, and during the 1930s she was an important part of the revolutionary movement in American literature. By 1940, however, she was out of fashion, and spent the remaining years of her life in frustrating obscurity. Only recently, because of mounting interest in the literature of the Depression, has she begun to be reevaluated. Harvey Swados has observed:

Of all the imaginative and rebellious writers of the depression decade, Josephine Herbst has been perhaps the most seriously underestimated and surely the most actively adventurous . . . With the exception of John Dos Passos, no other writer in the thirties had even attempted a fictional reconstruction of American life as sweeping and ambitious as Josephine Herbst's trilogy. . . . ${ }^{1}$

Selections from her novels and some of her sociopolitical essays have now been anthologized, while a biography and a collection of her memoirs are in preparation. Time has come for a reconsideration of her major literary achievements.

1 Harvey Swados, ed. The American Writer and the Great Depression (New York: Bobbs-Merrill Company, 1966), p. 103. 


\section{To Meet the Artist}

Born in Sioux City in 1897, to parents who had recently immigrated to Iowa from Pennsylvania, Josephine Herbst grew up "in that crotch of land made by the brutish Missouri and the racketing Big Sioux."2 Her family always had limited economic resources because her father's farm implement business never flourished. After two years at Morningside College in her home town, and one at The University of Iowa, she headed westward, eager to become a writer and determined to experience more of life than she felt Iowa could offer. She stayed in Seattle for a year, working and attending the University of Washington, then transferred to the University of California, where she received an A.B. in English in 1918. At Berkeley she had her first opportunity to publish, in the university literary magazine, and she also came into contact with anti-war student movements, encounters which awakened in her perhaps already-latent radical leanings. As a sign of her disapproval of the war she carried copies of the Little Review to classes "instead of a ball of wool to knit a sock for a soldier boy."3 Still footloose after graduation, she journeyed to New York, where she landed a job as a reader for H. L. Mencken's the Smart Set. In 1922, before the publication of her first short story in this magazine, she decided to leave for Europe.

She lived in Germany for more than a year, and began work on "Following the Circle," a novel she later completed but never published. Inevitably, after visiting Italy and England, she was drawn to Paris, the meeting ground for all literary "expatriates." Here she met many of the "lost generation" and established friendships with William Carlos Williams, Ernest Hemingway, and John Herrmann, whom she later married. After returning to New York, in 1925 she and John Herrmann moved to an old farmhouse in Preston, Connecticut, and, both eager to advance their careers, "gave themselves up to the splendors of isolation," 4 keeping a rigid schedule of writing during the day and reading and discussion in the evening. Other young artists, among them Katherine Anne Porter and Nathan Asch, arrived in Preston the following spring, and the town became a sort of informal literary colony. Shortly after, the Herrmanns went back to New York, without any money but with " 'the loot': manuscripts of two novels, a basket of currant jelly and summer tan."5

2 Josephine Herbst, "My Pennsylvania Dutch Home," Tomorrow, X (June, $1951)$, p. 19.

3 Josephine Herbst, "Yesterday's Road," New American Review, 3 (April, 1968), pp. 89-90.

4 Josephine Herbst, "A Year of Disgrace," The Noble Savage, 3 (May, 1961), p. 130.

5 Ibid., p. 136. 
By 1930 her short stories, which were appearing regularly in Scribner's Magazine and the American Mercury, and her two novels, Nothing Is Sacred (1928) and Money for Love (1929), which had attracted the attention of critics, established her as a well-known literary figure. During the decade of the Depression, however, she began to take an active interest in political dissent and no longer devoted herself exclusively to fiction. She traveled extensively as a special correspondent, writing articles for New Masses, Partisan Review, and the New York Post concerning such events as Iowa farm strikes, autoworkers' protests, the General Strike in Cuba, the Nazi regime, and the Spanish Civil War. She became acquainted with proponents of revolutionary literature, and although she never acted as an official spokesman for any group, she did incorporate the philosophy of socialism into her fiction. Her major literary achievement during this period, and perhaps of her entire career, was a trilogy, Pity Is Not Enough (1933), The Executioner Waits (1934) and Rope of Gold (1939), which offers a scathing interpretation of American society from the Civil War through the Depression. In 1936 she received a Guggenheim award in the field of the novel.

Since 1928 she had considered Bucks County, Pennsylvania, her home site, returning there whenever she was not traveling or working elsewhere. In 1941 she published Satan's Sergeants, a novel about this area and its people. After Pearl Harbor she volunteered her services to the Office of the Coordinator of Information in Washington, where she worked at the German desk, writing anti-Nazi propaganda for broadcast overseas. A few months later, however, presumably for her prior Communist affiliations, she was dismissed without official explanation and returned to Bucks County. Her last novel, Somewhere the Tempest Fell, came out in 1947.

Throughout the next two decades she continued to write, even though chronic illness and personal setbacks prevented her from completing many of her projects. She did publish a charming appreciative study of the Pennsylvania naturalist John Bartram in 1954, entitled New Green World, and that same year "Hunter of Doves," a novella based on her friendship with Nathanael West, appeared in Botteghe Oscure, a well-respected Italian periodical. She intended this novella as the first of a series of stories "about the writers in our times and their predicament," 6 yet it was the only part of the work which ever materialized. Nor did she finish her novel about the relationship of the 1920s to the 1940s, tentatively called "The Watcher with the Horn." In 1957 she received a Newberry Library fellow-

6 "Josephine Herbst," Twentieth Century Authors, First Supplement, ed. Sta1ley Kunitz (New York: H. W. Wilson Company, 1955), p. 438. 
ship for work on her memoirs, which she wished to be both a personal history and a commentary on American writing since the twenties. Unfortunately she completed only parts of this work. Two selections, "The Starched Blue Sky of Spain" and "A Year of Disgrace," appeared in The Noble Savage $(1960,1961)$, while a third, "Yesterday's Road," was printed in New American Review (1968). Josephine Herbst died in New York City in 1969.

\section{The Early Novels}

Much of the literature of the 1920s was permeated with a sense of antagonism toward the bourgeoisie. What was most harshly criticized was the arrogant and self-satisfied way in which this class lived, but no other aspect was spared. Its narrowness, its prejudices, its materialism, and its lack of refinement were all dissected. Apparently following this trend, Josephine Herbst centered Nothing Is Sacred on small-town, middle-class life and Money for Love on culturally unaware young drifters.

The very ordinary midwestern family in Nothing Is Sacred is introduced at the onset of a crisis threatening social disgrace and financial ruin because one of them has embezzled some funds from his lodge treasury. Part of what follows the opening scene, in which Harry Norland confesses his crime to his mother-in-law, sketches the reactions of the family members to the predicament his behavior places them in and their futile attempts to make him live up to his promise to reform. Along the way the author exposes the hypocrisy and the vulgarity of middle-class culture. Yet more than being an attack on the bourgeoisie, Nothing Is Sacred is a study in frustration. The economic issue illustrates this theme only on a superficial level, and as the narrative progresses it fades into the background, while the characters' private dramas, forced to the surface by the tension this crisis generates, take its place as the focus of interest.

Harry's stealing to support the ostentatious life-style he feels he needs to express himself as a real man and to strengthen his hold on his wife is emblematic of the psychological condition of the younger members of the family. Like him, each one feels hemmed in by external factors and longs to enlarge his horizons. In every case, however, their already limited aspirations are finally and effectively truncated by the pressures of blunt reality. In fact, as Harry ultimately runs the risk of going to prison, new disappointments also await all the others. Harry's wife, Julia, for example, wants emotional satisfaction. If for her this means having a romantic involvement like those presented in popular novels and ladies' magazines, this is because these are her primary sources of information about life. Her 
social-climbing husband cannot understand her need, and she turns to adultery, deliberately choosing a lover who courts her like a fictional suitor. Predictably, this lover's passion soon cools down, and Julia is forced to admit that her affair, besides being unsatisfying, is sordid and mean. In the same way, her elder sister Hazel's running around with a teen-age nephew in order to dodge the specter of middle age, and her younger sister Hilda's moving to Chicago and marrying a handsome but unstable young rebel to escape the restrictions of small-town life, prove useless when real problems intervene, toppling their dream worlds and leaving them pretty much back where they started.

The only character whose interior life remains relatively intact in this crumbling world is Harry's mother-in-law. Mrs. Winter's simple faith in the primacy of family life, the importance of sacrifice, and the necessity of patient loving, enables her to meet life courageously, something which the younger people, for whom "nothing is sacred," cannot do. Despite this, she too must come to terms with feelings of frustration. Somehow her daughters have become alienated from her. She would like to feel loved and respected by them; instead, she must steal their confidences furtively and content herself with unspoken manifestations of affection. She would like to teach them how to live, but since she knows they consider her principles outmoded she must watch helplessly while they flounder. Then, just as she hopes to reach that period of tranquillity for which she has expended so much of her energies, life starts slipping away from her, and she must resign herself to waiting for death.

In delineating these hapless searches for personal fulfillment the novel touches on bitter comedy, yet without turning into satire, since it is made clear that everyone is motivated by a legitimate desire for happiness. In particular, they seek love and a sense of personal worth. Repeatedly, however, they have failed to find these things, and after their latest defeats they retreat into self-pity and spiritual isolation, for they have no more inner resources on which to draw. This pattern appears so insistently, and is handled with such seeming objectivity, that it may be extended beyond these individual case histories to embrace a larger reality and to indicate that the quality of contemporary life, with its hollow values and its false promises, robs men of their vitality and impedes their moral growth.

The title of her second novel, Money for Love, accurately sums up its major action, for it deals with a young woman's attempt at double-edged blackmail-against a former lover, in favor of a current one-motivated by sentiments she considers love. As in the first 
book, the crisis provides the occasion for all the people involved to manifest their most hidden psychological conflicts and for the author to comment on the spiritual dryness of contemporary life. But this novel is so sparse and its characters so uniformly lacking in spirit that it ultimately turns in on itself. The author realized this. and later, in reply to one of her critics, admitted that she had written it according to a formula:

In Money for Love . . . I meant to get an overtone that would be more convincing than "reality." I succeeded so well that I never want to do this sort of thing again. But in adhering to this method I was under no compulsion to exalt "simplicity" but to attain a certain end. The machinery dominated the content in this case, and not by chance. ${ }^{7}$

\section{A Saga of the Working Class}

During the 1930s, Josephine Herbst, like many other writers concerned about America's grave socioeconomic problems, turned to Marxism. Hers was neither a sudden conversion nor a fashionable adherence to radical ideas. Already, in 1927, moved by the execution of Sacco and Vanzetti, she had begun that process of redefining her conception of the intellectual's relationship to society which in the next few years would take her "as far left as you can go." 8 Her political journalism throughout the 1930s, based on contacts with protagonists of crucial uprisings at home and abroad, attests to the depth of her convictions and to her acceptance of rebellion as a justifiable reaction to decades of repression. The most concrete illustration of how profoundly socialist ideas entered her world view is, however, her decision to engage her talents in writing a fictional critique of America's social, political, and economic institutions.

She did not have to search far for suitable material because she carried in her intellectual baggage a store of information about her own family, which had participated in many of the great adventures of the American people since pre-Revolutionary days. As she once wrote:

I was brought up on my mother's nostalgia for the East, and her admiration for those members of her family who had ventured, often to their downfall, dramatized for me my entire conception of American life. . . The family for generations had kept

7 Josephine Hexbst, "Counterblast," The Nation, 132 (March 11, 1933), p. 275.

8 Josephine Herbst, "Yesterday's Road," p. 103. 
diaries and letters, and the first inkling $I$ had of the complexity and significance of people in relationship to each other came from these documents. Living seemed constantly fertilized and darnned by the tragic burden one generation passes to the next. 9

She would, of course, need to turn the facts of her family history into fiction, and to fill in the background necessary to conunicate the flavor of the eras through which these people had lived. Most of all, she would need to interpret their "tragic burden" so that their lives could serve as a convincing accusation against the capitalistic base of American society. These were the tasks facing her as she began work on what, over the course of nine years, would become the Trexler-Wendel trilogy: Pity Is Not Enough, The Executioner Waits, and Fope of Gold.

To transform her family's history into "a saga of the working class," Josephine Herbst tumed to literary "collectivism." This technique, then popular, excludes a single hero and aims to encompass as many different lives and problems as possible, advancing them simultaneously and making the overall effect of the work more important than any one of its characters or issues. But if a collective work conveys a general sense of the chaotic process of history, its lack of a focal point may impede achieving an artistic synthesis of effect. The nature of her subject matter, however, helps har overcome this problem, for she structures her collective trilogy around the experiences of one family. Since the members of this family wander so much and since they attempt so many ventures, she can distribute her narrative over different periods and geographical areas and still have a coherent point of reference, and she can also make this family's experiences emblematic of the movement and aspiratious of the American people. In addition, as each generation carries with it the memory of those who came before, and participates in the hardships of those still living, this use of a single family provides the trilogy with emotional continuity. Another problem posed by the collective technique, the apparent absence of a controlling point of view, she resolves by placing brief passages before each major subdivision. These inserts, by commenting ironically on the family chronicle, help to make clear the historical significance of the action in each book and of the trilogy as a whole.

9 Josephine Herbst in "Josephine Herbst," Twentieth Cenitry Auhors, eds. Stanley Kunitz and Howard Haycraft (New York: H. W. Wilson Company, 1942). p. 641 . 
Pity Is Not Enough traces the experiences of the family from after the Civil War to the turn of the century. The bulk of the narrative deals with "Poor Joe" Trexler, who in 1868 leaves his povertystricken family in Philadelphia and heads south to make his fortune. After two years of prosperity, generously shared with those at home. his world collapses. The Atlanta railroad company for which he works becomes the center of a huge scandal, and he, who played only a minor role in the colossal wrongdoings, becomes the scapegoat. Although all his cohorts later receive pardons, he always remains a fugitive. Having once tasted the fruits of easy wealth, he cannot rest until he finds another shining opportunity, and for the remainder of his life he crisscrosses the West, prospecting gold and speculating in land. Unluckily his energy and optimism cannot offset his lack of business sense, and he always loses out to the bigger operators until, after thirty years of continual frustration, he dies penniless and insane.

Joe's younger brother David, in contrast, after a childhood as the petulant darling of his harried mother and sisters, heads west toward real success. More able than his elder brother in scenting out surefire ways for money-making, he soon begins trading:

The soldiers at the fort were loaded with flour but had little money for gambling and whoring. David bought their flour dirt cheap and sold it to prospectors not fifty miles away at 400 percent profit. He felt good about his sharp deal. It just showed he could take care of himself. Well, if a man didn't, nobody else would and it was all a question of the survival of the fittest. ${ }^{10}$

From then on David knows how to "take care of himself." None of the other Trexler children fares as well as he. Catherine, who worshipped Joe, dies young, collapsing under the strain of too much worry and the shock of learning that her beloved brother was really guilty. The eldest son, Aaron, who takes on the burden of the family during Joe's lean years, withdraws irrevocably into himself after his mistress dies in childbirth. Anne marries, and in the late 1880 s, with her husband Amos Wendel, moves to Oxtail, Iowa, "a thriving place, just on the boom." 11 But for them, as the inserts predict, "boom" ultimately spells bankruptcy.

The chronicle of the "first generation" is presented through a

10 Josephine Herbst, Pity Is Not Enough (New York: Harcourt, Brace and Company, 1933, p. 309.

11 lbid., p. 332 . 
series of scattered episodes which are, in turn, set against the inserts. These, which refer to the beginning of the twentieth century, focus on Anne Trexler Wendel and her four girls during long years of poverty in lowa. Since neither the Trexlers in the story line nor the Wendels in the inserts fully understand the significance of Joe's tragedy, or the reasons why almost no one in the family manages to fulfill even very ordinary ambitions, much of the book's meaning derives from an ironic juxtaposition of these two parts. In the inserts, Anne's girls are first shown reacting with pity to their mother's stories about her brother; only later, when they feel that their own lives are plunging toward defeat, do they realize that for Joe, as for them, "pity is not enough." Despite this, they do not know just what would be "enough" to prevent such catastrophes in the future. The story line, instead, suggests that Joe, granted his moral flexibility, was always the tool of unscrupulous men, and that the two adventures he took part in, the "rebuilding" of the South and the "exploration" of the West, were largely based on corruption and self-seeking. It also makes David's rise to wealth, won by neglecting his less fortunate relatives, and at the cost of human decency, a harsh commentary on the "self-made man." In this way the novel's "past" indicts the growth of a profit-motivated order for the disintegration of America's ethical and moral ideals, while its "present" illustrates how the passivity of the American people before the injustices of that economic order perpetuates its sway over the course of their lives.

The Executioner Waits picks up the story during World War I and carries it through to the eve of the Depression. The Wendels now take center stage, although considerable attention is given to David Trexler and to the upper-middle-class family of Jonathan Chance, the future husband of one of the Wendel children. During the years prior to the action, the fortunes of the Wendel family keep spiraling downward, until in 1914 Amos goes bankrupt. His wife Anne, unable to give up hoping for better times, spends her whole married life trying to pay off debts and dreaming how she could help her girls if she just had some money.

Their four daughters grow up in Iowa, accustomed to a life of continual sacrifice and apprehension for the future. The elder ones marry and try to settle down to conservative middle-class lives. Clara, whose husband has a decent job, manages well enough; Nancy and her husband must move constantly in search of work. The younger ones, Vicky and Rosamund, emerge from their impoverished childhood with vision and determination. Unlike the other members of the family, they reject the typical American model of success, having seen enough of its unpleasant aspects in their uncle 
David, and after attending college at great sacrifice they begin to wander in search of some place where they can live purposefully, using their learning and vitality. But the "curse" of the Trexler family is on them too, and Rosamund is the first to feel it. When her husband returns from the war, the two of them move to Detroit, where she tries in vain to help him adjust to a society which now seems to have no place for him. Defeated in their struggle to achieve economic independence, they return to Iowa. Shortly, still stunned by the apparent impossibility of ever escaping from the same hopeless poverty which has always haunted her parents, she dies in a car accident. Vicky's wanderings finally take her to New York, where she falls in love with Jonathan Chance, a renegade from his upper-middle-class background. They marry and move to Pennsylvania, but a chronic lack of money and the psychological problems which assail him complicate their young lives. Toward the end, they become interested in radical politics, and he starts to work as a Communist organizer in the area.

David Trexler, all this while, continues his economic ascent in the Far West, multiplying his capital as that region expands and reaching the apex of his career with some shrewd trading during the war. Nonetheless, he still slights his poorer relatives and so dominates his children that they show signs of personal maladjustment.

In this volume Josephine Herbst makes clearer the philosophy underlying her tale of the crumbling ambitions of the middle-class. Amos, Vicky, Rosamund, and all the other unfortunate members of this family are "losers," yet as their stories take shape it becomes apparent that they have many fine qualities which, in a more just society, would have enabled them to live productively. Even David Trexler and Jonathan's possession-obsessed parents are shown to be victims of the system, for in the pursuit of wealth they destroy all their nobler sentiments. David, for example, although he cannot resist taking advantage of the possibilities war offers him for making money, harbors anti-war sentiments.

The relationship between the family chronicle and external society also becomes more evident. Much important social detail is woven into the narrative. Numerous episodes-an Industrial Workers of the World convention in Oxtail, a general strike in Seattle, a brawl between picketers and scabs in Detroit-show the characters reacting to some facet of life in this tumultuous period in American history. The inserts, which no longer refer to members of the central family but to protagonists of farm and industrial protests from 1932 to 1934, help coordinate the events of the story line with the explosive years of the Depression. Through them the characters' 
association with current issues takes on prophetic overtones, as Amos participates in the failure of the small businessman, Rosamund's husband in the plight of the returning veterans, and Vicky and Jonathan in the restlessness of the "lost generation" and the rise of radicalism.

The accelerated pace, the increased social reference, and the sharper ideological focus of The Executioner Waits make its condemnation of capitalism more intense than in the first volume of the trilogy. As the narrative shifts from place to place and from character to character, pausing just long enough to highlight the private and external contours of each particular situation, it firmly and economically emphasizes the social tension which, as the title indicates, will soon explode into a stormy class war. The novel ends, in fact, with capitalism trembling before the threat of unified action from below. In the closing scene, suggestively set in a graveyard, David Trexler, the trilogy's most important "man of success," witnesses the burial of a murdered striker. As the dead man's friends, joined together in angry sorrow, pay tribute to him by chanting the words of Joe Hill, "Don't mourn. Organize," David Trexler

shivered on the ignored edge of the crowd but when the yellow lumps of earth began to fall, he shuddered as if they were falling into his own grave upon his own unprotected flesh. The crowd stood tight, a hard nucleus like a fist that would never open, and he looked toward it for sympathy for David Trexler, the little orphan, but it was staring at the grave and did not see him. ${ }^{12}$

Rope of Gold spans the bitter years from 1933 to 1937 and covers more territory than either of the previous volumes, for it ranges from Seattle to Cuba, with stopovers at many points between. The inserts, here roughly contemporary with the action, again focus on crucial protests during the Depression. While still predominantly a family chronicle, this novel also offers detailed portraits of farmers, factory workers, industrialists, and pseudo-intellectuals. All of these people, in the story line and in the inserts, in America and abroad, are shown split into hostile camps, struggling bitterly against one another.

The pressure of the crisis disturbing much of Western society is reflected in the stories of the four principal characters. The first

12 Josephine Herbst, The Executioner Waits (New York: Harcourt, Brace and Company, 1934), p. 370. 
two, Vicky and Jonathan Chance, initially go on working energetically for the revolution, he as a grass-roots organizer, she as a reporter specializing in strikes and the labor movement. But their persistent financial worries and personal problems eat away at their onceresilient optimism and sour their marriage. Toward the close, Jonathan wearies with the struggle, while Vicky, always the stronger of the two, stifles her disillusionment and continues to support the cause she has undertaken.

The third major figure, Steve Carson, is a midwestern farm youth obliged to seek a low-paying factory job after being forced off the land by debts and prolonged crop failures. For several years he tries unsuccessfully to fight alone for economic security. After he comes into contact with people engaged in planning organized protests against big business, however, the radical sentiments he inherited from his father, an adamant socialist, rekindle, and he decides to voice his dissent openly by taking an active part in the labor struggle.

As in the first two volumes, here too the narratives of those fighting to stay alive are contrasted with tales of success. The most fully developed of these refers to Ed Thompson, Jonathan's brother-inlaw. Endowed with the reactionary ideas and the worship of money which Mr. Chance tried to pass on to Jonathan, Ed rises to an executive position in an auto company. His expertise in squelching rebellions and in intimidating workers assures him of an excellent salary and the praise of the owners of the business. Nevertheless, like all successful men in the trilogy, he diminishes himself by poisoning his family life and by ruthlessly manipulating those around him.

Despite the political conversions of proletarian characters like Steve Carson, and hints of successful challenges to the system on the part of many workers, Rope of Gold is far from being a triumphant conclusion to Josephine Herbst's trilogy. The radical transformation of American society, called for in Pity Is Not Enough, and predicted in The Executioner Waits, never takes place. But something else happens, and the novel registers this change with astonishing sensitivity. Everywhere in the book people suddenly realize that something has gone terribly wrong: faith fails the minister delivering a sermon over the body of a murdered protester because "of what use to preach the Kingdom of God when the kingdom of earth was a living pit"; 13 anxiety grips the farm couple who realize that "the Bank had its hands on their shoulders, stood by their bed, pulled the shoelaces from their shoes"; ${ }^{14}$ anger explodes in the in-

13 Josephine Herbst, Rope of Gold (New York: Harcourt, Brace and Company, 1939 ), p. 380.

14 Ibid., p. 52. 
dustrialist who thinks that "he had put everything he had, as the saying is, into one basket. And that basket proved to have a hole in the bottom"; ${ }^{15}$ desperation enervates the worker who feels like a diseased man "to know that he had escaped death only to linger for no one knows how long helpless on his spine."16 The very texture of life seems to be disintegrating. Like the drought which turned vast areas of America into creeping deserts during the Depression, the economic inequalities and the social and ethical compromises inherent in the capitalistic system have finally sapped the lifeblood of the nation's people.

\section{The Shadow of Sin}

The usurpation of life and land by the rich and the distorting effect of private guilt are the two themes around which Satan's Sergeants revolves. The author details in a documentary way the particular situations of more than twenty inhabitants of a small Pennsylvania village, contrasting them ironically to underscore social injustice and stressing certain similarities which give force to her moral concern. In developing the theme of guilt she also introduces a symbolic level of meaning into her story, depicting the town as a fallen Eden, and suggesting that each inhabitant bears the burden of his own "original sin."

The social theme is dealt with straightforwardly. The once-lush farm country around Merlin is slowly being transformed into a seasonal resort by wealthy urban people who buy up and remodel land and old farmhouses for summer use. As the rich increase in number, the poor are pushed off the land and either hire themselves out as helpers on private estates or find work in nearby factories. For years these descendants of the original Pennsylvania Dutch

had gradually washed down from the higher once rich ridge to the lower levels as if they were part and parcel of some vast soil migration that might carry little pebbles and particles of earth and humans alike silently to some deep river. ${ }^{17}$

Between the town's two groups of residents there is little comradeship. The natives regard the wealthy as intruders, while the latter, whose interests really lie elsewhere, make no effort to understand the problems of those around them. Only at one point in the story do

15 Ibid., p. 422.

$16 \mathrm{Ibid}$., p. 226.

17 Josephine Herbst, Satan's Sergeants (New York: Charles Scribner's Sons, 1941), p. 2. 
they join together in a common enterprise, that of battling a fire which threatens to destroy the estate of Mr. Elliott, the richest man in Merlin. The townspeople's concerted efforts save his land, and although his barn collapses he immediately receives word that his insurance company will reimburse him fully for this loss. When compared to the outcome of another episode, this happy conclusion serves to stress how far apart the rich and the poor really are. Johnny Amstrong, the son of the village postmaster, dies in a freak accident in the paper mill. The owners, who originally hired him because "the best fellas for the mill are the young ones . . . their muscles are soft see, they aren't set yet," 18 use the boy's being underage as an excuse for refusing his family any benefits. Obviously. the poor are eligible neither for compensation nor for compassion.

The author's attack on the theme of guilt is more complex. As the lives of Merlin's varied inhabitants come into focus, it appears that they are all unhappy in consequence of some past error which makes them strangers to whatever might have given meaning to their existence. Mrs. Willard, cultured and wealthy, accuses herself of cowardice because after the death of her first husband she married a man she never could love, and because she has allowed herself to become spiritually paralyzed under his influence. Sam Purcell, a rich writer, lives in torment because in exchange for success and freedom he betrayed his literary ideals and alienated his wife. Martha Purcell realizes that the sterility of their relationship is in part due to her having wanted marriage "as one falls in love with a landscape and takes whatever house has been built on it."19 Johnny Armstrong"s mother traces her troubles to having married when she was already secretly carrying him, the fruit of her first love affair. Her husband struggles under his own enormous private burden, the memory of having accidentally killed a child when he was a motorman. This pattern continues throughout the novel. Character after character scrutinizes his past, repeatedly upturning the tainted underside of his life and revealing how this has deprived him of the right to personal happiness and meaningful human relationships.

The fact that none of the characters nourishes illusions of innocence, indeed that many of them mourn eternally for the guilk they see in themselves, does not by itself render their essentially discrete stories a unified investigation of the way in which guilt perverts life. In an attempt to yoke together these portraits, the author superimposes on them a mythic framework, paralleling Mer-

18 Ibid., p. 83.

19 Ibid., p. 167. 
lin to an Eden in rot, and hinting that her characters are all, in one way or another, "satan's sergeants." In spite of its beauty and richness, for some time life has not taken root in Merlin. The inhabitants no longer live in harmony with nature, as the early settlers did; poverty and wealth alike have broken the natural cycle. Human behavior has also intervened, permitting social injustice, separating husbands from wives, and condemning individuals to actual or living deaths. If Merlin were once really an earthy paradise, it is now an inferno. During the fire it takes on a hellish aspect: "The sky had thickened with a roll of smoke and against the darkness a tiny rim of fire crawled up to the very edge of the world."20 Even when nature is dormant, Merlin's people move through hells of their own making. Because of some failure, each has been "pitched out of Paradise," and the memory of that moment haunts them incessantly, darkening their own lives and the lives of those around them forever.

Unfortunately, Josephine Herbst does not fully realize the meaning of the myth of the Fall. She introduces it only occasionally and fails to make its presence felt throughout. As a result, it is not able to sustain the burden of thematic resolution which she seems to have wished to impose on it. Nor does the fact that she tries to combine two basically distinct types of themes and modes of narration facilitate her unifying the novel artistically. If Satan's Sergeants fails on a symbolic level, and if it lacks a single firm controlling element, it nevertheless deserves praise for the way it evokes, in many of its separate narratives, a sense of the tormented impasses that life can bring.

\section{The Self in Crisis}

What interests the author most in Somewhere the Tempest Fell is the question of personal identity, especially the way in which time and memory as well as individual and collective behavior shape human destiny. The central characters, Adam Snow and Ada Brady, both experience identity crises, and both undertake the arduous task of confronting their past and present in order to restructure integral self images. Their situations are further reflected in those of numerous lesser characters, plagued by an analogous sense of displacement. In the words of one of them, they have all been "slugged by history": personal recollections and the memory of public tragedies over the last two decades oppress and shatter them. Josephine Herbst had often touched on this idea before, but hitherto she had never made it her primary concern. In her earlier work

20 Ibid., p. 150. 
she divided her attention more equally between individual and social issues. Here her focus is directed almost exclusively on the inner lives of her characters. Society is not completely slighted, however, for when these dislocated individuals come together they offer an image of a world off-balance, a world sorely in need of redefining its own identity.

Adam Snow, a commercially successful writer of mystery stories, discovers at the height of his career that he has lost his self-awareness and decides to abandon "George Wand," his fictional detective, and to search for his own identity. Initially he thinks he would like to recapture the past, since there he locates romantic purity and moral fervor, ideals symbolized by Lucia, his first love, and by his association with anti-Fascists during a long stay in Italy. Soon, however, he realizes that the past is full of shadowy and unresolved issues. While his love for Lucia was actually untarnished, he has let her image overshadow his relationship with his wife. His political behavior, he now sees, was never very brilliant. His sympathy for the Resistance did not mature into concrete action, and once he might even have inadvertently betrayed an Italian partisan. What first appear to be embodiments of a lost perfection thus become emblems of Adam's guilt feelings about the whole course of his life. He begins to wonder if he ever knew himself at all, and if not, how he can expect to reshape himself now.

In a less intense way, Ada Brady's story repeats the same predicament. She feels that since the breakup of her marriage she has lost touch with what is alive around her. She hopes to forget her private sorrow and to involve herself in a meaningful social context by becoming a patroness of the "new music." To this end she remodels her home and transforms the basement into a retreat for jazz musicians. Despite this, her failed marriage continues to haunt her, and, although she takes a few hesitant steps toward the future, she carries with her the past's doubly painful sting of loss and shame.

Almost every other character recognizes in himself the same groping for identity and the same confusion about the real meaning of his past. Ralph Johns, a gifted historian and journalist, had tried to tell America what was happening abroad in the 1930s, had tried to caution her about the approaching catastrophe:

He had warned stop Japan in the early days of Manchuria, stop Italy, stop Hitler, stop Franco in Spain, but the traffic had roared past the uplifted hands of the volunteer Boy Scouts. Then he had stopped yelling Stop, frozen in doubt as to how to stop whom, terrorized by the vision of a momentum that might have 
astronomical dimensions, that might begin in one place and end unpredictably somewhere else. ${ }^{21}$

No one listened, and his belief in the power of words, in his own power, gradually degenerated into sterile cynicism. Harry Light, a former socialist organizer, likewise once felt purposeful; then changing historical conditions upset the philosophy which had informed his life, leaving him feeling like "an old actor with the stage empty, the audience departed, the myth he was to have lived by . . . still fluttering persistently in his heart." 22 In a more private way Melvin Gregg, a mathematician whose work revolutionized the field of economics, also structured his life around a laudable goal. Nonetheless, he too is appalled at the hollowness of his present life and at his inability to carry on further research. For each of these characters the principles around which they once organized their lives no longer seem viable. They feel like fragments rather than whole men, and each one lives out a version of Adam Snow's struggle to understand his past and to redefine his concept of himself.

Somewhere the Tempest Fell communicates in a new and poignant way that mood of disillusion with life which has so often characterized the fiction of Josephine Herbst. This novel, however, suffers from her inability to work the strands of her narrative together sufficiently; too often they seem parallel when they should be interwoven. This technical weakness is also a sign of a deeper failure in conception, indicating that while she was able to imagine the quality and tone of each part, she was unable to connect them and to draw from their interrelation the general ideas indispensable for passing from specific case histories to novelistic insight.

As suggested, Josephine Herbst's novels reflect innovations in style characteristic of the three decades during which she wrote. Her twenties' books, which embody something of the strain and crisis of the times, are written in the concise, economic manner of her contemporary Ernest Hemingway, while in the trilogy, where social and economic concerns are emphasized, she employs the techniques of documentary realism typical of much fiction of the thirties. Later, during the forties, in novels dealing with moral problems and the crisis of personal identity, she experiments with symbolism. All her books, however, work through exhaustive presentation. She does not focus on the fortunes of a single protagonist; rather she weaves together a number of equally important parallel narratives. Such a

21 Josephine Herbst, Somewhere the Tempest Fell (New York: Charles Scribner's Sons, 1947), p. 21.

22 Ibid., p. 317. 
structure permits relatively little space for any one character or issue. Nevertheless, she succeeds in conveying a profound feeling of the brevity of life, the pathos of experience, and the mystery of time and memory.

If over the years the author revised her mode of expression, she always kept faith with what she conceived of as the final aim of fiction: "The artist seeks to tell us what the world is or isn't; what it should be or even what it cannot be outside the realm of some transcendent dream." 23 In fact, throughout her career, she endeavored to study man in relation to an actual world, to understand him as a product of his age and class and to discern how external factors, as well as that dark dilemma which is life itself, shape his destiny. Thus, although some of her novels are near-achievements rather than major accomplishments, all of them offer a challenging commentary on the nature of the human condition.

23 Josephine Herbst, "Ubiquitous Critics and the Author," The Newberry Library Bulletin, V (December, 1958), p. 3. 


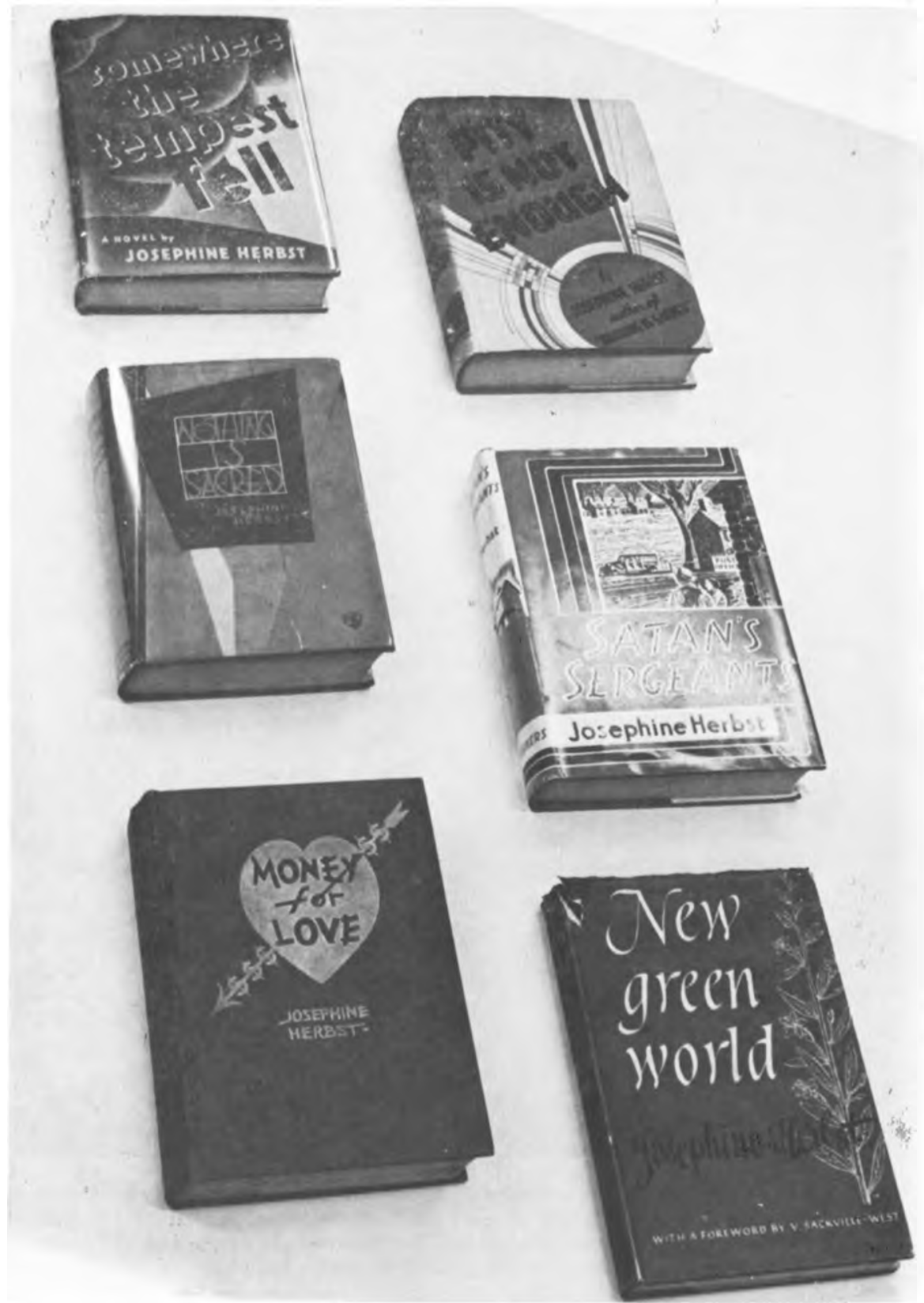

Six books by Josephine IIerlst, published between 1928 and 195.4. Pity Is Not Enough (19:33) is the first volume of her Trexler-Wendel trilogy. Her last book, New Cireen World (1954), is a biography of the early American botanist John Bartran. From the lowa Authors Collection. 